\title{
Rural Marketing Mix
}

\author{
N. Md Faiyaz Ahmed \\ M.Com, M.Phil, NET, Assistant Professor, \\ Commerce (Finance \& Accounts) \\ Islamiah College (Autonomous), Vaniyambadi, Tamil Nadu, India
}

\begin{abstract}
The buzzword today in the Marketing Industry is "Rural Marketing"; reportedly three times that of the European Market, the Indian rural market is a huge untapped resources almost half of the national income is generated here. Rural market offers new and greatest opportunities to manufacturer. MNC's and Indian companies alike are now plugging into these huge markets.
\end{abstract}

India is a country where the majority population, almost $70 \%$ lives in villages, there are 627000 villages in the country spread across its length and breadth. There are 25 official languages and some four hundred dialects spoken in the country; most world religion has their adherence here.

Gone are the days when village were using neem or babul tree to twig for cleaning their teeth, today they are using ultra bright shine of Colgate or some other international brand of tooth paste instead of groundnut the children are asking for chocolate candies that will meet in their mouths, face cream or lotions have replaced besan (chickpea flour) as a face cleanser.

Things are changing fast now in rural India. Literacy level increasing, people in village become conscious about their life style and about their rights to live a better life. Brand consciousness is on the rise, this clubbed with increasing disposable income of rural households, has made the rural market more demanding market today.

\section{Rural Market:}

One having population of less than 5000 .

$75 \%$ of male population engaged in agriculture.

$2 / 3$ of a country's consumers live in rural area.

$50 \%$ of national income is generated by the rural population.

\section{Rural Marketing}

Is the process of developing, pricing, promotion distributing rural specific goods and services to exchange between urban and rural markets which satisfy consumer demand and also achieve organizational objectives.

\section{Profile of Rural Consumer:}

$>$ Literacy Level:

It is estimated that the rural India has 23\% literacy as compared to $36 \%$ for the whole country. Every year 60 lakh is getting added to the literate population of rural India.

$>$ Income Level:

Income level of rural consumer have grown in the last one decade, still an average rural consumer has a much lower income than urban counterpart. Low purchasing power, low standard of living, low economical and social positions are the traits of rural consumers. 
Reference Group:

In rural place the reference groups are primary health worker, doctors, teachers, village traders, and grocery shop owner.

\section{Occupation:}

Typically in rural area the principal occupation is farming, trading, crafts and other jobs like plumbing, electric work etc, one also finds primary health worker and teacher.

Media Habits:

A rural customer is fond of music and folklore. Now television, radio, newspapers, magazine, video films are a part of the traditional media other variables.

Culture, linguistic, religion, caste and social customs are important variables for profiting a rural consumer.

\section{What Make Rural Market Attractive}

$>$ Rural Indian boys

- Products more often (mostly weekly)

- Buys small packs, low unit price

$>$ In rural India, brands rarely fight with each other.

$>$ Brands are building strong rural base without much advertising support

742 million people.

$>$ Estimated annual size of the Rural Market

- FMCG $57 \%$ of total sales (toothpaste, soap, shampoo)

- Durable $59 \%$ of total sales (toothpaste, soap, shampoo)

- Telecom $71 \%$ of total subscriber.

More than $60 \%$ of Indian income comes from rural

$>$ Rural India accounted for almost half of the India retail market

- Hariyali Kisan Bazaar (DCM)

- Aadhars (pantaloon, Godrej, JV)

- Choupal Sagars (ITC)

- Kisan Sansar (Tata)

- Reliance Frens

- Naya Yug

More than $60 \%$ of Indian income comes from rural
$>$ Rural India offers, a business opportunity worth US\$ 487 million According to a survey it will grow to US $\$ 1.9$ billion by 2015

$>$ Out of $78 \%$ households having awareness about like insurance in rural India..

> Indian pharmaceuticals market regarded as one of the fastest growing market - almost $45 \%$ of the growth is from rural area

Of two millions BSNL mobile connections, $50 \%$ in small towns/villages and farmers are using mobile phones to call other farmers to find out the market price for corps like rice, fruit, and coconuts.

42 million rural households (HHs) are availing banking services

\section{Marketing Mix:}

\subsection{Product}

The various product levels as outlined by Philips Kotler, namely core Benefit, Expected Product, augmented products and potential product should be adequately taken into consideration in rural product also. Most of the times in the urban product the product is offered at the augmented product, But in the rural markets in India is operated in the Expected Product section where his expectation are met, due to the low level of income and literacy level.

Today in India 70 percent of the shampoo market is in sachets. Forty percent of rural workers are daily wages earners and have a daily purchase habit and could do so because of low unit price packs.

In case of durable goods the rural customers essentially look for a product that is frill-free, sturdy and long lasting and in case of consumer goods he looks for product that operates at the basic level and can provide additional benefit in synchronization with their habit and lifestyle.

\subsection{Price:}

A significant portion of the rural population is paid in daily wages. Daily wages earner tend to have little stock of money and therefore tend to make purchases only to meet their daily needs. The implication is that pack sizes and price are critical to sales in rural market. 


\subsection{Promotion:}

"If you're trying to persuade people to do something, or buy something, it seems to me you should use their language, the language in which they think" David Ogilvy

In India's rural areas where only one in every three households owns a television set and more than half of all villagers are illiterate, companies need to turn more innovative methods of advertising to reach their potential customers. Also what appeal to the urban customers may not appeal to the rural customers due to varying lifestyles. Few of the available traditional media are

$>$ Puppetry
$>$ Folk Theatre \& Songs
$>$ Wall painting

\subsection{Physical Distribution:}

For most companies wanting to enter the rural markets, distribution poses serious problems. Distribution costs and non availability of retail outlets are major problem faced by the marketers.

\section{a) Rural Marketing Vehicle (RMV):}

Marketers needs to make more on - ground contact with their target audience as well as make demonstration of products as consumer in rural markets rely on the "touch and feel" experience. One of the ways could be using the company delivery vans which can serve both the purpose and it take the products to the customers in every nook and corner of the market and it also enables the firms to establish direct contact with them.

\section{b) Melas and Haats:}

According to the Indian Market Research Bureau, around 8000 melas are held in rural India every year and annual sales at melas amount to Rs. 3,500 crores. Besides these melas, rural markets have the practice of fixing a specific day in a week as Market Days where exchange of goods and services carried out. Also every region consisting of several villages is generally served by one satellite town where people prefer to go to buy their durable commodities.

\section{Innovation:} Sophisticated Power tolls or rural areas. A wide range of wood working, construction and metal working tools catering to the needs of rural carpenters, metal working, artisans, plumbers are carried. The tools are available to rural artisans at subsidized prices. Bosch has tied up with several banks including Canara Bank and Andhra Bank, - to attractive loan scheme for the rural folk to buy these tools.

\subsection{Shakti:}

Shakti is a very innovative program of Unilever, for distribution of FMCG goods to rural population. Unilever trains rural women in order to improve their selling skills and turns them as Uniliver's saleswoman.

\subsection{Chaupal Sagar:}

It has been initiated as a rural shopping - cum information center. It has been set up by the International Business in M.P. division of tobacco major ITC.

\subsection{E-Chaupal:}

Is the backbone of these rural malls. It provides the farmers necessary information about weather \& prices. It will provide them another platform to sell 
their produce and purchase necessary form and household goods under the same roof. E-chaupals combines a web portal in the local language and PCs with internet access placed in the villages to create a two-way channel between ITC and villagers.

\section{Challenges in Rural Marketing:}

\subsection{Transportations:}

Transportation infrastructure is quite poor in rural India; many of the rural India remains outside the railway network. As regard road transport, nearly $50 \%$ of the villages in the county are not connected by road at all. Many parts in rural India have kacha roads and many parts of the rural interiors are totally unconnected by roads. As regard carriers, the most common mode is the animal drawn cart, because of these accessibility, delivery of products and services continues to be difficult in rural areas.

\subsection{Warehousing Problems:}

In warehousing too, there are special problems in rural context. Business firms find it quite difficult to get suitable go downs in many parts of the rural India.

\subsection{Communication Problems:}

Communication infrastructure, consist of posts and telegraph is quite inadequate in rural areas, since communication is the first requirement of efficient marketing, lack of proper communication infrastructure poses difficulties, especially in physical distribution.

\subsection{Channel Management:}

The distribution chain in the rural context requires large number of tier, compared with the urban context. The long distances to be covered from the product points and the scattered locations of the consuming cause this situation. In addition there is the problem of availability of dealers.

\subsection{Poor Viability of Retail Outlets:}

Sales outlet in the rural market at the retail level suffers from poor viability. A familiar paradox in rural distribution is that the manufacturers incur additional expenses on distribution and still the retail outlet finds that the business is not remunerative to them.

\subsection{Inadequate Bank Facilities:}

Distribution in rural markets is also handicapped due to lack of banking and credit facilities. Rural outlet needs banking facilities to remittances to principals and to get fast replenishments of sock, to receive supplies through bank etc.

\subsection{Seasonal Demand:}

Demands of goods in rural market depend upon Agricultural Situation, as agriculture is the main source of income. Agriculture to a large extent depends upon monsoon and therefore the demand or buying capacity is not stable or regular.

\subsection{Traditional Life:}

Life in rural areas is still governed by customs \& traditions and people do not easily adapt new practice. For exp, even rich and educated class of farmers does not wear jean or branded shoes.

\subsection{Buying Decision:}

Rural consumers are cautious in buying and decisions are slow and delayed. They like to give a trial and only after being personally satisfied, do they buy the product.

\section{CONCLUSION:}

Thus looking at the challenges and the various opportunities which rural markets offer to the marketers it can be said that the future is very promising for those who can understand the dynamics of rural markets and exploit them to their best advantage. Rural marketing is the marketing of new millennium. Marketer has to understand the rural customer before they can make road into the rural marketing.

\section{REFERENCES:}

1)Dogra, Balaram and Shuman, Karminder, (2008) Rural Marketing: Concepts and practices, TATA McGraw- Hill Publishing house, New Delhi. .

2) Singh, Sukhpal Rural Marketing: Focus on Agricultural inputs, (2008) Vikas Publishing House, New Delhi.

3)Gopalswamy.T.P'Rural Marketing" Wheeler Publishing,2004.

4)Kumar Singh, Awadesh and Pandey, Satyaprakash" Rural Marketing- India Perspective" New Age International Publisher, New Delhi, 2005 